\title{
Public Library Services and the Information Needs of Women in Northern Nigeria.
}

By

Ghaji Badawi (Ph.D)

\begin{abstract}
Nigeria was a British colony that became independent in 1960. It is the most populous state in Africa. Northern Nigeria comprises of $62 \%$ of Nigeria's land mass and $53.7 \%$ of the national population. Majority of the people in northern Nigeria are Muslims and the culture of these people reflects largely Islamic influences. Western-style education was introduced into the southern part of Nigeria by Christian missionaries in the mid 1800th. On the other hand, it took the Europeans another 64 years to establish the first primary school in the north in 1907. European form of education was initially rejected by the people of the north regarding it as a threat to their culture and religion. For many years people were not willing to send their children (especially girls) to those schools. Early marriage was popularly supported by most families and large percentages of girls were rarely allowed to attend formal western schools or go beyond primary school education. As such, greater percentage of the population but most especially the female population in Northern Nigeria could not read. Public Libraries in northern Nigeria were also rejected as alien by the community because they were stocked by the British with documents written in the English Language. Very few people could read at that time and the few that could, only read documents written in Arabic. After independence, the aspiration to develop and the desire for education encouraged political leaders of Northern Nigeria to build more schools in towns and villages and girls were encouraged to attend. Within thirty years after independence, the numbers of pupils (especially females) in all educational institutions have increased tremendously in the region. The increase in literacy among the population increased the level of library utilisation and this encouraged the governments of northern Nigeria to increase their support for libraries.
\end{abstract}

\section{Introduction}

Public libraries and their services in Northern Nigeria since the $1980^{\text {th }}$ are experiencing boost particularly in terms of infrastructures, collections and public support. They are now integrated into the cultures of people especially women. Public libraries play crucial roles in the empowerment process of women now popularly supported by governments and NOG's. Public libraries now have become part of the culture of people and libraries are stocked with materials suitable for everybody. This has given governments in the north the courage to invest in public libraries. As democracy takes firm root, public libraries are playing their roles in the social, political and educational development of females in their communities. Public libraries in Northern Nigeria have been part of the new trend of female educational, economical and political empowerment through the provision of services needed to satisfy their information needs. Public libraries now have an active interaction with all citizens in the region through technological and multi-interest events. These activities also lead to a greater strengthening of democracy, since open communication permits citizens both males and females to exercise a better degree of choice and control.

This paper discusses how public libraries in northern Nigeria have developed and their efforts in providing females with services and resources to help in their educational, political and economic development.

\section{Brief Description of Northern Nigeria}

Nigeria was a British colony that became independent in 1960. It is the most populous state in

Africa (FMIC: 2001). The National Population Commission gave the 2006 Nigeria census figure as 140,003,542 million (NPC: 2007), $51.22 \%$ of the total population were males and $48.77 \%$ were females. Nigeria is a country of great diversity because of the many ethnic, linguistic, and religious groups that live within its borders. For administrative purposes, the country is divided into 36 states and a federal capital territory. 19 of these states constitute Northern Nigeria.

Northern Nigeria comprises of $62 \%$ of Nigeria's land mass and $53.7 \%$ of the national population. It borders with the Sahara from the north and has a long relationship with the Arabs from the north and eastern Africa. Majority of the population in Northern Nigerian are Muslims and the culture of these people reflects largely Islamic influences. Traditionally people of the north are largely farmers and traders; women also trade. .

\section{Western Education in Northern Nigeria}

Western-style education was introduced into southern Nigeria by Christian missionaries in the mid 1800th. By 1914, there were sixty eight primary and eleven secondary schools in the southern region of the country. On the other hand, it took the Europeans another 64 years to establish the first primary school in the north in 1907. This was mainly because European form of education was initially rejected by the people of the north regarding it as a threat to their cultures and religions. For many years people were not willing to send their children (especially girls) to formal schools and as such, in the $1900^{\text {th }}$, western 
education continued to develop at a very slow pace in the region. For example, in 1914 there were only 1,100 primary school pupils in the north, compared with 35,700 in the south and there were no secondary schools in the north compared with eleven in the south at that time.

After independence 1960 to 1980, people in the North realized they needed to acquire formal education to enable them compete for economic and political development with the southern part of the country. Primary schools were established in cities and villages. Secondary schools and Teacher Training Colleges were opened in all major towns. The first university in Northern Nigeria was opened in 1962 and by 2009 of the total 27 Federal and State Universities in the country 14 are in the north (NUC 2007). Northern political leaders became great advocates for education in their regions and large percentages of annual budgets were spent on promoting education. The following is a sample table showing the tremendous growth of primary and secondary school education in one of the 19 states of northern Nigeria within four decades (Kano State ):

\begin{tabular}{|c|c|c|}
\hline YEAR & $\begin{array}{c}\text { Primary } \\
\text { Schools }\end{array}$ & $\begin{array}{c}\text { Secondary. } \\
\text { Schools }\end{array}$ \\
\hline $\mathbf{1 9 6 4}$ & 42 & 08 \\
\hline $\mathbf{2 0 0 4}$ & 3,526 & 757 \\
\hline
\end{tabular}

Source: The Nigerian Statistical Fact Sheets on Economic \& Social Development. National Bureau of Statistics. Abuja, Nigeria

The population of students in all types of schools and colleges both males and females have dramatically risen in the region. This has risen the number of people who can read and write which in turn has increased the utilisation of libraries by a more literate population. Since the dawn of the colonial era, Western influences have challenged, threatened, and in certain ways enriched the lives of people in Northern Nigeria.

\section{Women And Education In Northern Nigeria}

Education is a critical factor in human life. It is a strong basic ingredient to the total development of people in societies. Traditionally, female involvement in formal schooling in northern Nigeria was extremely low. This was due to both cultural barriers against educating girls and resistance to western forms of education. For many years, early marriage was popularly supported by most families and large percentages of girls were rarely allowed to attend formal western schools or go beyond primary school education. As such, greater percentage of the population but most especially the female population in Northern Nigeria could not read or write. This was most prominent with population from the NorthWestern part of the region.

Illiteracy among women in Northern Nigeria was a great impediment to their participation in decisionmaking. Women in this region were therefore not in a position to protect their interest as their counterparts in the Southern parts of the country and their lack of early access to formal and functional education did reduce their involvement in development process. This situation lasted from the early 1900 to the early $1970^{\text {th }}$.

\section{ADVOCACY: From Awareness to Support}

A growing awareness of gender disparities in Northern Nigeria has led to increased efforts by united bodies, governments and NGO's in the region and the country to gather statistics from researches done on women and to point out the male-female discrepancies in areas such as education, health and economics. For instance, the 'Better Life' program was established in 1987 to raise the social consciousness of women about their rights as well as stimulate and motivate women towards achieving better, higher standards of life through education, political participation and economics. Many other women associations and NGO's were formed in the Northern states between 1980 and early 1990 to bring women together for better understanding and revolution of their problems through collective action. Since then, the number of female students in primary, secondary and universities soared up. Women in the region now are increasingly demanding for equality of access to education and jobs with men and the ratio of female/male in education is now almost equal with the southern part of the country 
Statistics of female/male students in both primary and secondary schools in Kano, Northern Nigeria in 1964.

\begin{tabular}{|c|c|c|c|c|c|c|c|c|}
\hline \multirow[t]{2}{*}{ YEAR } & \multirow{2}{*}{$\begin{array}{l}\text { PRIM. } \\
\text { SCHOOLS }\end{array}$} & \multicolumn{3}{|c|}{ STUDENTS } & \multirow{2}{*}{$\begin{array}{l}\text { SEC. } \\
\text { SCHOOLS }\end{array}$} & \multicolumn{3}{|c|}{ STUDENTS } \\
\hline & & MALE & FEMALE & TOTAL & & $\mathrm{M}$ & $\mathrm{F}$ & TOTAL \\
\hline 1964 & 42 & 10454 & 1306 & 11760 & 08 & 2297 & 720 & 3017 \\
\hline \multicolumn{2}{|c|}{ \% Male/Female } & 88,90 & 11.10 & $100 \%$ & & 76.14 & 23.86 & $100 \%$ \\
\hline
\end{tabular}

SOURCE: STATE UNIVERSAL BASIC EDUCATION BOARD, KANO, NIGERIA

Statistics of female/male students in both primary and secondary schools in Kano, Northern Nigeria in 2004.

\begin{tabular}{|c|c|c|c|c|c|c|c|c|}
\hline \multirow[t]{2}{*}{ YEAR } & \multirow{2}{*}{$\begin{array}{l}\text { PRIMARY } \\
\text { SCHOOLS }\end{array}$} & \multicolumn{3}{|c|}{ STUDENTS } & \multirow{2}{*}{$\begin{array}{l}\text { SEC. } \\
\text { SCHOOLS }\end{array}$} & \multicolumn{3}{|c|}{ STUDENTS } \\
\hline & & MALE & FEMALE & TOTAL & & $\mathrm{M}$ & $\mathrm{F}$ & TOTAL \\
\hline 2004 & 3,526 & 924,299 & 780,549 & $1,704,848$ & 757* & 297,108 & 165,093 & 462,2 \\
\hline$\% \mathrm{Mal}$ & Female & 54.22 & 45.78 & $100 \%$ & & 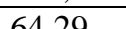 & 2571 & $100 \%$ \\
\hline
\end{tabular}

Source: 2008 National School Census: Secondary School Management Board.

*This number did not include the number of private schools in the state.

Women who were refused access into education when they were young are now joining Adult Education Literacy Schools to empower themselves with education. Thousands of women in Northern Nigerian can now be found working in Academics, Health, Finance and Politics.. They are longer quite as repressed and are now rubbing shoulders with men in all endeavours of life in the region and beyond.

\section{Public Libraries in Northern Nigeria}

Public libraries had a very late beginning in the Northern states of Nigeria. While the first library in Nigeria was established in the southern part of the country in the 1870s, the first public library or Reading Rooms (as they were initially called) in Northern Nigeria were first set up in the 1940's.

At first, Libraries in northern Nigeria were regarded by the local people as alien. This was because libraries initially stocked only books and newspapers written in the English Language and in those early years, majority of people in Northern Nigeria could not read. The few that could, only read documents written in Arabic. For that reason, most of the population in Northern Nigeria seldom ventured to use libraries.
After Independence in 1960 but most especially from the late 1970s, Northern Nigerian wanted to develop educationally like the south and the desire for education gave the impetus to political office holders to support public library services. Decision makers and financiers in the region became library supporters and friends. Library Boards were established in each of the 19 states with library headquarters in state capitals and branch libraries spread in villages. Mobile library services were also provided for remote areas that were hard to reach. Library edicts were promulgated to guide librarians and promote library services.

Unlike public libraries in most parts of Nigeria, and indeed most African communities, public libraries and their services in Northern Nigeria are experiencing boost particularly in terms of infrastructures, collections and support. In the last twenty years most state governments have renovated or complete re-located their main public library buildings to suitable locations and more branch libraries were built in villages. Due to these developments, the population of library users has grown tremendously the last twenty years

Comparison of Statistics of Users in Kano state public library - January, 1989 and January, 2009

\begin{tabular}{|c|c|c|c|c|}
\hline \multirow[t]{2}{*}{ YEAR } & \multicolumn{4}{|c|}{ MALE / FEMALE USERS } \\
\hline & MALE & FEMALE & TOTAL & $\%$ OF USERS \\
\hline Jan. 1989 & 1820 & 420 & 2240 & $\begin{array}{ll}81.25 \% & \text { (Males) } \\
18.75 \% & \text { (Females) }\end{array}$ \\
\hline Jan. 2009 & 3395 & 1750 & 5145 & $\begin{array}{lr}65.98 \% & \text { (Males) } \\
34.02 \% & \text { (Females) }\end{array}$ \\
\hline \% Increase & $186.53 \%$ & $416.66 \%$ & $229.68 \%$ & \\
\hline
\end{tabular}

Source: PSLB Library Statistics Records 
It is predicted that the continuing increase in the number of students in our schools and the increasing variety of services offered by public libraries in the north will lead to further growth in demand for public library services in the region.

\section{Funding}

Most public libraries in Africa depend on their governments for funding; that is true for all public libraries in Northern Nigeria too. To supplement finances many of them involve themselves in community activities - for fees. They provide spaces, music, electronic gadgets, computer/media services and even catering services for weddings, religious services, naming ceremonies, political party meetings, business meetings etc. These really do bring extra income to public libraries. Again, public libraries and public librarians also established advocacy between their libraries and local organisations, government offices, traditional chiefs, influential groups for support. This friendship helps public libraries get both financial and moral support from their communities.

\section{Library Resources}

Initially, public libraries only stocked books written in English and that was what made them unpopular among majority of northern Nigerians at that time. Now, public libraries stock books and journals in different Nigerian and foreign languages and like most public libraries in the country, the largest resources are books and journals. Public libraries in the north are reasonably well stocked with books and journals. The main public library of Kano has more than 460,000 books and journals in its stock.

Majority of main public libraries in Northern Nigeria have good computer/internet services in their main branches. Internet/computer services are often free to users. The IT section of the Bayero University library , Kano is the largest academic library internet service in the country and it is free for its users .

\section{Circulation Service}

All public libraries in the north provide facilities for borrowing books. This service is provided to registered library members and also to institutions on interlibrary loan agreement. Most public libraries in this region have very large reading spaces. But because of staff shortages, operating hours are inadequate and the circulation desks are often manned by very few junior staffs that are frequently impatient and short-tempered.

\section{Staffing and Users}

Staffing is big problem for all public libraries in this region. This issue has been discussed at several 'Directors' of Northern Nigeria Public Libraries' Annual General Meetings without solution. In Nigeria, Public librarians are civil servants working for their state governments. They are on the same salary scale as the rest of the civil service. Government salary scale is less than half that of private organizations or universities in Nigeria. As such, librarians working in private organisations or universities are paid more than twice the public librarian. This could be the factor behind the shortage of librarians venturing into public library service. To date for example, Kano State Public Library with four very large floors, serving an average of 700 users every day has only 9 librarians and 13 library technicians. This shortage often results in poor library service especially at the circulation desks and other reader services departments.

Another problem is the absence of female users in public libraries in the north. This is most obvious in Shariah states and many librarians including myself have researched into this problem. Though a democratic institution, our cultures often clash with the culture of libraries and many fathers and husbands would not allow their wives or daughters to venture into public places such as public libraries and mingle with the opposite sex. Many researchers have advised library boards in Shariah states to provide separate reading areas for females away from men whenever possible.

\section{Library Legislation, Edicts/ Acts}

Since 1968, each library board in Nigeria is charged with the responsibility of public library development in their states. Each state formulates its policies in the light of their needs, recourses and local conditions. The Library Edict of each state was established in the year the library board was set up. For example the 'Kano State Library Edict' was established in 1981 with the establishment of the state's 'Library Board'.

\section{Library Association in Northern Nigeria}

Public librarians in Northern Nigeria are active in the Nigerian Library Association. Majority of State Chapters in the North engage in social and professional activities throughout the year. For example the Kaduna State Chapter just recently concluded a one month 'Children Story Telling Competition' through out secondary schools in the state. In Kano, the Nigerian Library Association 
State Chapter held its Annual General Meeting and elected its executive committee in March 2009.

\section{Information Needs Of Females In Northern Nigeria \\ Information on Education:}

Women in Northern Nigeria have for a long time understood they needed education to empower themselves and they are now seeking education in schools and other similar institutions and organisations that could help. Public libraries in our region are not left behind in helping women achieve this objective. For example, even though parents do not pay school fees for primary and secondary education, text books, school meals, transportation etc cost a lot of money which many of parents could hardly afford. Many young girls are withdrawn from schools and married off because their parents could not afford to pay these expenses. Of these school expenses, text books cost the most money. Public libraries in Northern Nigeria in their effort to encourage the entrance and retaining of girls in primary and secondary schools acquire and make available approved school text books in their collections. These text books are sent to all branch libraries in local governments where school children, boys and girls could go and use them. Mobile library services are also available to schools on demand in some states. Public libraries also provide internet services for students to access information that they need for their studies and for leisure.

Public libraries with extra spaces even loan out part of their buildings to be used to as teaching classes and as vocational centres for women. Public library venues are used for short term courses, lectures etc particularly as Adult Education classes to local women. Public libraries particularly participate and organise school activities to help create more awareness of libraries to young people. Annual reading and story telling competitions between primary and secondary schools are organised by public libraries and students are encouraged to join. These public library competitions are always publicise in the local media and prizes awarded by public libraries to winners.

Through branch and mobile library services, public libraries are now providing information to women in rural communities in the form of youth information projects, aiding gender meetings and providing information centres and relevant resources for women in the communities. A new service to women in Purdah is on the drawing board in Kano state. The objective of this new service is to take the library into the homes of women who cannot visit the library themselves. When this service starts, female librarians will be assigned to visit homes to register and find out the reading interests of women and then desired books would be delivered and loaned to the registered women on a monthly loan period.

\section{Information on Health}

HIV/AIDS and Malaria have almost reached an epidemic state in Nigeria (Medical Newsletter: 2002). Nigeria is now the second country with the highest number of people living with HIV/AIDS after South Africa with an estimated number of 2,600,000 people living with HIV/AIDS in the country. This means that families are being stretched to the limit. The number of women being riddled with full blown AIDS increases daily and the death toll is growing. In Kano state alone, it was revealed that there was an average increase of $2.7 \%$ of new HIV/AIDS cases each week. A startling revelation from the statistics collected and carefully kept by AKTH, IDH and MMSH hospitals in Kano was that over $61.7 \%$ of all cases of AIDS were females (KSMH:2005) . Most female HIV patients in the state, as well as in the whole region were poorer than male patients and could not afford their medication even though the drugs were heavily subsidized and in some cases free. Because of these factors, female patients rapidly become consumed by full blown AIDs. The ratio of death from diseases related to HIV/AIDS between female and male patients studied was 3:1 (AKTH Statistics Unit: 2005/6) respectively.

Public libraries in this region quickly realised the need for them to propagate information to women and girls about HIV/AIDS with the intent to help increase awareness and help control the spread of this disease among the population in general and women and children in particular. Public libraries have become common ground for providing proactive prevention-focused AIDS information services. Libraries liaise with media houses to coordinate information programs on HIV/AIDS. Documents on HIV/AIDs and Malaria are acquired, organised and disseminated to branch and mobile libraries to create a more informed society about these killer diseases.

In 2005, IFLA president opened a centre for Information on AIDS in Abuja, Nigeria; since then numerous other branches of this centre have been opened under the auspices of the National Library of Nigeria. Such involvements of the library in social problems of the country have enhanced the image of public libraries and have increased their utilization by females in both rural and urban areas of Northern Nigeria. 


\section{Information on Politics:}

"We, women politicians of Nigeria viewed with concern that the past efforts of our women towards political emancipation and contributions of our past heroes have not yielded desired fruitful results inspite of the fact that women form over $60 \%$ of voters.” (Adado, 2006)

From the history of Northern Nigeria, cultural factors constituted a serious source of problem for the development of women politically and those cultures have continued to affect the development and prominence of women in their roles in politics. Traditions and cultures regard women as attachments or subordinates to men even where women have excelled in education, ability or performance. These traditions did not help women in their bid to empower themselves politically but for many decades have succeeded in keeping women more in the background of events, especially where leadership and political participation are concerned.

"One of the stake holders of ensuring maximum participation in the upcoming election has been said to be (among others) libraries and information centers in the country. These agents of communication and education could assist in no small way with raising awareness of females in their responsibility to participate in the 2007 election and in fact all other forthcoming political activities.” (Badawi: 2007)

In the 2007 Nigerian election, public libraries in the north played a big role in enhancing political awareness of women voters through sharing information with local communities especially females about local contestants. Public libraries even allowed their premises to be used as debating and meeting centers for all political office contestants. Local women political office aspirants made regular use of public libraries for debates and political party meetings. Libraries collected and made available Information i.e biographies of local contestants and many women political aspirants made good use of the library to display their campaign posters and documents about themselves and their political parties and aspirations. Public Libraries in northern Nigeria attained high popularity of their people during the electioneering year of 2007 which gained them greater advocacy with the new political office holders and fatter budgets since then.

\section{Information on Economics:}

The development process of any nation is closely linked to the progress of women and must be predicted on women's unhindered contributions to economic advancement. In effect though, there are glaring imbalances in access to economic decisionmaking which have made women the majority of people living in poverty in this region. This economic powerlessness constitutes a great barrier to women asserting their rights and achieving economic freedom.

People of Northern Nigeria are now harnessing all resources available to them for the purposes of promoting economic development. They are increasingly realizing that an intolerable waste of human effort cannot enhance sustainable development. Thus, there are demands, (even in the most rigid Sharia states) for women to sit at tables (with men) where decisions that affect the economic and political destiny of their people are made.

The establishment of Poverty alleviation programs such as the "Family Support Program" the "Family Economic Advancement Programme" and many other such programs from the 1980s to date were aimed at helping women achieve economic empowerment among other things. But women need access to information about such programs and how they could benefit from them. Public libraries in Northern Nigeria have since 1987, been advocates of such women programs. They have formed advocacy between themselves and these bodies encouraging meetings, organising workshops and even opening sections dedicated to the collection and dissemination of documents about or related to women programs and women studies in the region.

\section{Conclusion}

Due to culture and circumstances, Public Library services started on a weak footing in Northern Nigeria. From the mid $1980^{\text {th }}$ onwards, the desire for economic and political development encouraged the Northern Nigerian Government to improve and expand public library services. Public libraries now have become part of the culture of people in northern Nigeria and libraries are utilised by individuals, groups and organisations in the region for verity of purposes. This has motivated governments in the north to invest more in public libraries. As democracy takes firm root in the country, public libraries are playing their roles in the social, political and educational development of females in Northern Nigeria.

Public libraries in the region have been part of the new trend of female educational, economics and political empowerment through the provision of relevant services to satisfy their information needs. Public libraries in this region now have an active 
interaction with citizens through technological and multi-interest events. These activities are leading the people to a stronger democracy, permitting women to exercise a better degree of choice and control over their destiny.

\section{References}

Federal Ministry of Information and Culture Tourism in Nigeria (2001) Abuja: FMIC Vo. 1 , no. 4

National Population Commission.(2007) "Census 2006” Census News Abuja: NPC. Vol. 1 no.1 pp. 8 - 24.

Nigerian University Commission (2007) Statistical Report: 2007 Abuja: NUC Vol 2. no5 pp. 12

State Universal Basic Education Board (2006)

" Enrolment Trends " Education Statistics in

Kano SUBEB: Kano, Nigeria.

Secondary School Management Board (2005)

"Statistics of female/male Students in Primary

2 and Secondary Schools in Kano” 2008 National School Census: SSMB: Kano, Nigeria

Public Library Board (2010) "Statistics of Users" Reader Services’ Records _KSPLB: Kano, Nigeria

Medical Newsletter (2002). "Controlling HIV/AIDS in Nigeria”. KSMH: Government Printer, Kano,Nigeria .

Pelatona, M. "HIV/AIDS in Southern Africa: women at risk" in The Journal of Diseases Control SAHMI, Durban South Africa.

AKTH, IDH and MMSH (2005) Statistics of HIV/AIDS patients KSMH, Kano, Nigeria.

AKTH Statistics (2005). "Ratio of Male/Female AIDS Patients" AKTH Statistics Units, Kano.

Adado, H (2006) female participation in Nigerian politics. Lagos, Nigeria, Bodous Publishers, Nigeria

Badawi, G. (2007) “Libraries and women's Participation in Nigerian Politics" IFLA Journal IFLA: $\quad$ Vol 33 no. 